\title{
A Proposed Geoheritage Inventory System: Case Study of Isalo National Park, Madagascar
}

\author{
Hasina N. Randrianaly', Andrea Di Cencio², Aroniaina Rajaonarivo ${ }^{3}$, \\ Tsilavo Raharimahefa ${ }^{4}$ \\ ${ }^{1}$ Département de Paléontologie et d'Anthropologie Biologique, Faculté des Sciences, \\ Université d'Antananarivo, Antananarivo, Madagascar \\ ${ }^{2}$ Geology \& Paleontology Technical Studio, San Casciano Val di Pesa (FI), Italy \\ ${ }^{3}$ Isalo National Parks, Ihorombe, Madagascar \\ ${ }^{4}$ Deparment of Geology, University of Regina, Regina, Canada \\ Email: rhasinanirina@gmail.com, andrea.dicencio@gmail.com,aro_nyaina@yahoo.fr, raharimt@uregina.ca
}

Received 22 February 2016; accepted 22 May 2016; published 25 May 2016

Copyright (C) 2016 by authors and Scientific Research Publishing Inc.

This work is licensed under the Creative Commons Attribution International License (CC BY).

http://creativecommons.org/licenses/by/4.0/

(c) (i) Open Access

\begin{abstract}
Geological heritage inventory procedures and templates have been principally emerged from European countries. Each of these countries has developed its proper method of inventory based on its natural heritage, recognized on local and/or regional scales. Natural sites were mainly identified and characterized in a particular geological context, which is usually very unique, valuable and impressive; resulting in the protection of the sites. Madagascar is known internationally as a beautifully landscaped island, but the impressive sites were not cataloged. We carried out a series of field inventory of potential geological sites within the Isalo National Park in southern Madagascar. We invented several inventory sheets in order to record the most detailed information about the sites identified within the park. This is to aid in organizing the park and to establish a sustainable base for the creation of a geopark, and also they help us to build a database for geosites and their classifications. This article suggests a prototype model for inventorying intangible geosites, paleosites and geomorphosites. Our inventory sheets help to identify and to promote geological importance of any sites, not only for academia but also for other sectors such as tourism and conservation.
\end{abstract}

\section{Keywords}

Inventory Sheets, Geoheritage, Geosites, Paleosites, Geomorphosites, Park National, Isalo Park, Madagascar 


\section{Introduction}

During the last decade, the concepts of sustainable development and ecotourism have expanded globally and have become as the most important parts of the geoconservation and valorization of geoheritage [1]-[4].

In developing countries such as Madagascar, these two concepts should combine the idea of the process by which a country uses to improve key sectors (economic, health, education and gender) and the environmental awareness that is essential for protecting the natural environment (biodiversity and geodiversity) [5]. Thus, several nations developed a plan of action to promote natural geological heritage in order to improve the protection of the environment [6]. Many authors already proposed different techniques that might be used to identify and classify geological sites; these sites must be unique, unusual, having a particular geological context and well preserved and deserve to be highlighted and protected [7]-[9]. In order to protect these sites (geosites, paleosites and geomorphosites), we need to identify and promote them not only for the sake of sciences but also and more importantly for the development of a sustainable tourism in such areas.

In Madagascar or in any other African countries, conservation is primarily focused on rare and endangered species and is used to draw the attention of national and international communities on the issue of conservation sites [10]-[12] while expressions of interest on the valorization of geological interest in socio-economic and tourism related sectors are limited or non-existent, which limits the scope of implementation efforts [5], [13] and [14]. Accordingly, the aim of this paper is to establish a prototype sheets for inventory of geoheritage appropriately adapted not only for Madagascar but also for other developing countries. Despite the existence of different types of inventory sheets [15]-[22], there has been only limited and a few inventory sheets that can be used directly for Madagascar`s geosites, hence a new compiled inventory ones are made to overcome the issues.

\section{Methodology}

\subsection{Typology of Geological Sites for Inventory: Geosites/Geomorphosites/Paleosites}

Considering the designation of the geological sites proposed in many geologic and geographic literatures (Wimbledon et al., 2000 [15], Reynard et al., 2007 [16], Iosif, 2014 [23], Giusti \& Calvet, 2010 [24] and Golonka et 2014 [25]) and the main works of Ielenicz, 2009 [26] and Lugeri et al. [27], which distinguished the geotope/ geosite to the geomorphosite in order to classify the tourist value of the site; Table 1 was established as a classification flow of geological features adopted in this present work. This classification is more flexible and easy to use in the field; in addition it can be used for complex geosites not only the rare geosites but also geosites with noticeable changes over a short-time period.

\subsection{Proposal Prototype Sheets of Geosites/Geomorphosites/Paleosites Inventories of Madagascar}

The inventory of geosites, paleosites and geomorphosites are crucial and very important for the purpose of integrative regional development ([7] [28]-[30]).

This work focuses on Isalo National Park, a park that is already protected. The preliminary approach to the implementation process of geoconservation shows without any doubts the abundance of natural heritage within the park, particularly the geosites [14].

Taking into account all relevant bibliographical revision which aim to recognition of every possible geosite inventories, the methodology of this paper is based on different approaches suggested by many researchers ([16]-[22], the Italian Superior Institute Superior for Environmental Protection and Research (ISPRA: "Istituto Superiore per la Protezione e la Ricerca Ambientale”) and Madageoheritage. Accordingly, Madageoheritage has

$$
\text { Table 1. Typology of geological sites used in inventory sheets. }
$$

\begin{tabular}{|c|c|c|c|}
\hline $\begin{array}{l}\text { Basic typology of the site } \\
\text { Characteristic }\end{array}$ & GEOTOPE/GEOSITE & GEOMORPHOSITE & PALEOSITE \\
\hline CODE & GEOT & GEOM & PALE \\
\hline Common characteristic & & Geologic objects having heritage values & \\
\hline Spatial value & Geological unit & Geological unit, largest part of relief & Paleontological unit \\
\hline
\end{tabular}


proposed the prototype sheets of geosites/geomorphosites/paleosites inventories of Madagascar [5]. Because of many similarities between geosites found in Madagascar and abroad the inventory sheets were inspired from the descriptive sheets of ISPRA and were modified to fit the Malagasy geosites (recording more detailed characteristics and focusing more on the rarity and complexity of Malagasy geosites).The sheets were also designed for both previously known and unknown (potential) geosites and will be used by the Madagascar National Parks (MNP) at Isalo National Park [31]. The inventory sheets can assess the distribution of geological sites within the national parks and they can be used to categorize the sites according to their scientific and touristic values. Geosites of scientific importance can be valued as educational sites and those with tourism value can be used to promote geotourism; both will help to reduce local poverty.

\subsection{Description of Inventory Sheets}

The sheets were constructed using Canevas 12 software and were designed to be used in the field (Figure 1) and to be converted into a digital format (Figures 5-7) for the compilation of digital database.

\section{Inventory sheet number one}

Figure 2 shows all information and criteria used in the inventory sheets followed by explanation in order to compile the general data on the geological site:

- Information of the protected area and the geological site: property, toponym, location coordinates; identification code and the compiler.

- Detailed graphic presentation of the geological site: picture and geological map.

- Scientific interest which generate the assessment, contextual interests and scientific interest degree.

- Compiler: name of the compiler or symbol of the institution (university; association, NGO...) (e.g. Madageoheritage).

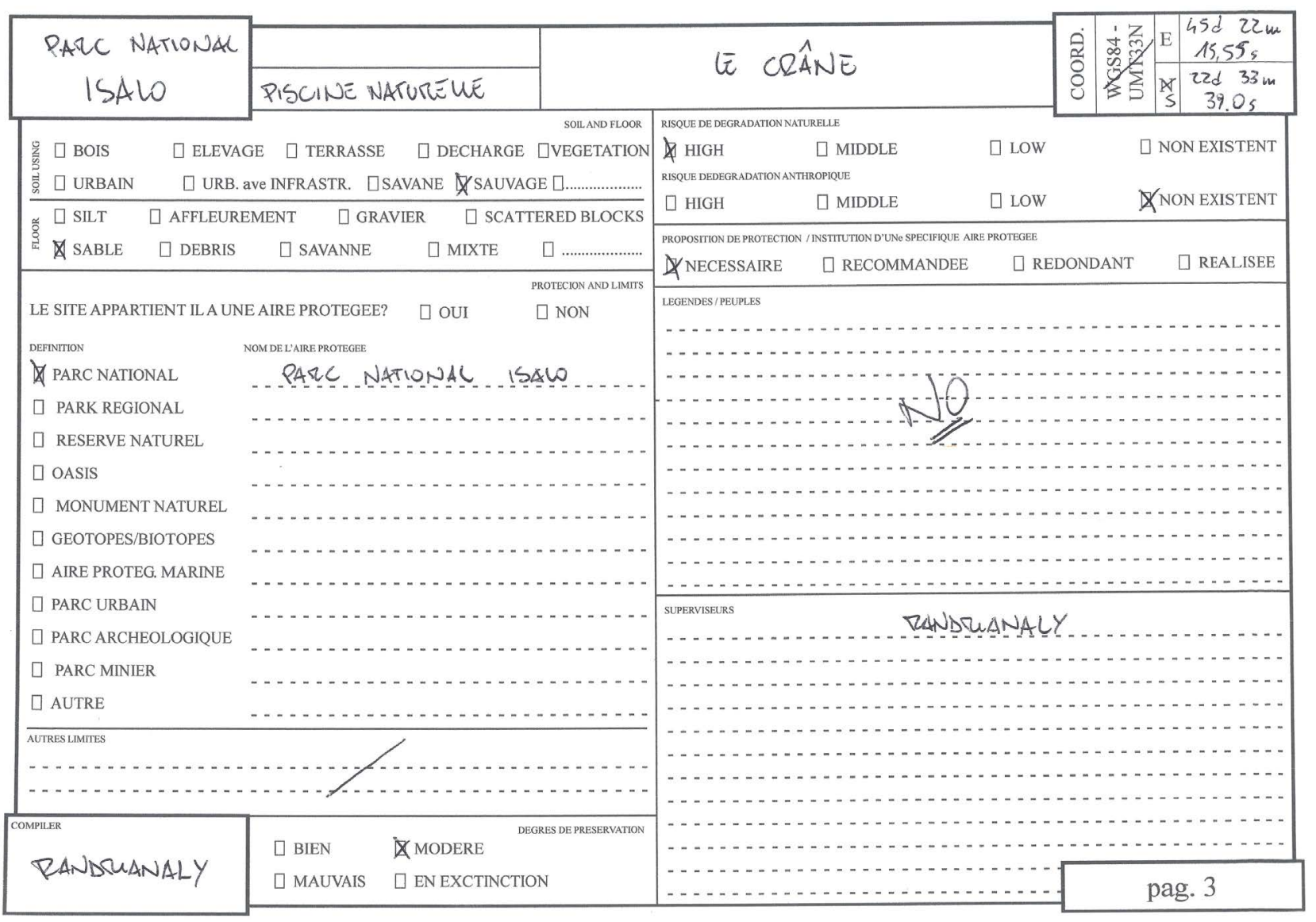

Figure 1. Model of inventory sheet "number three” filled during the fieldwork in Isalo Park. 


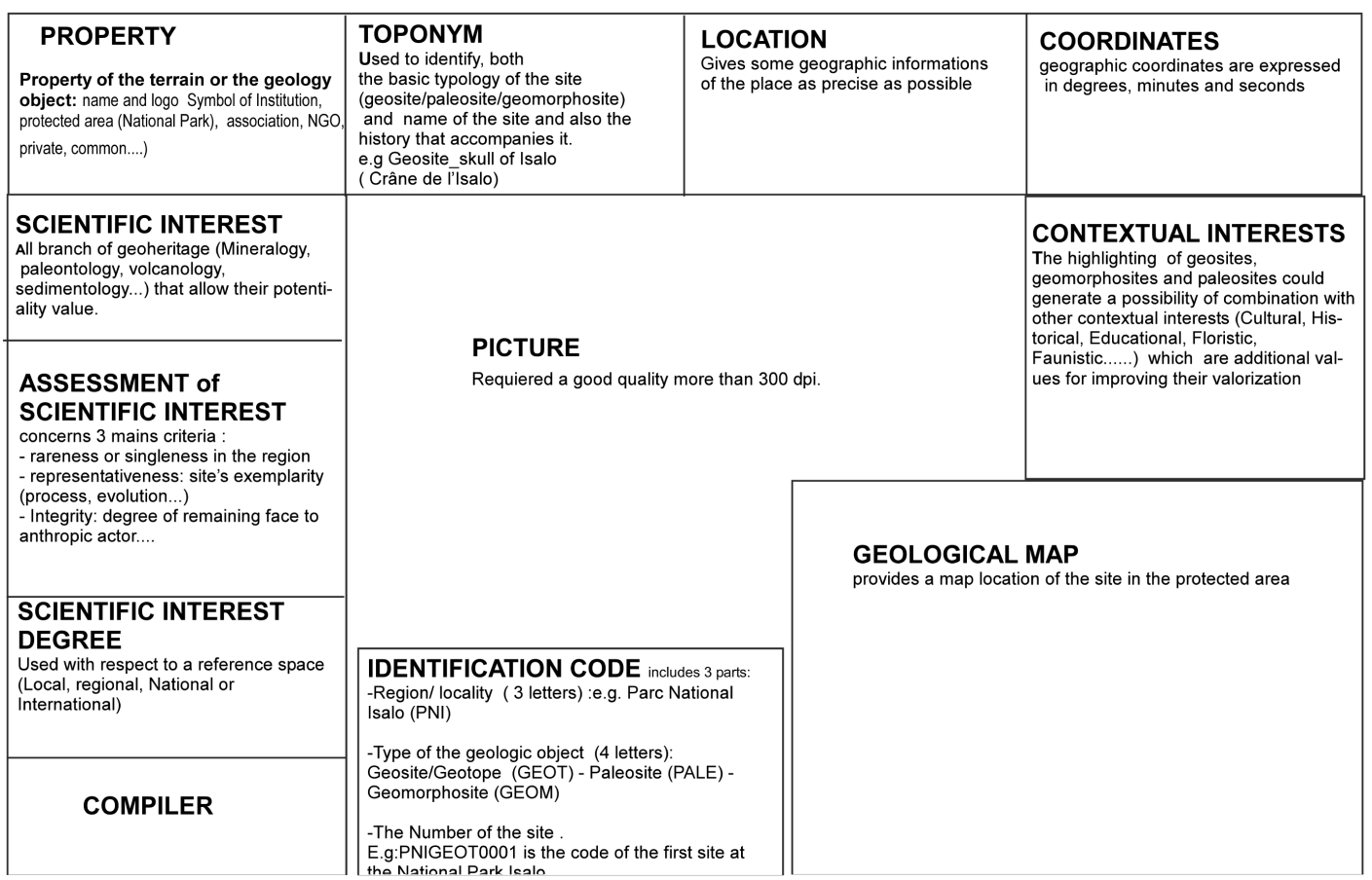

Figure 2. Prototype detailed of inventory sheet "number one”.

\section{Inventory sheet number two (Figure 3)}

The sheet is divided mainly into two parts, except the header, which is the same for all cards.

- On one side, the description of morphogenesis of the site. Under this strand are defined geological values of the site: general and genetic description, lithology and morphogenesis.

- On the other side are all of the characteristics of the site: typology (single or combination of elements); Structure of the area (e.g. punctual, panoramic); originality; the position of the site (in surface or submerged); accessibility (on foot, vehicle, bike or other): degree of accessibility (easy, hard, inaccessible) and season suggested for the visit.

Inventory sheet number three

Figure 4 represents the inventory sheet number 3 and is designed to collect any other secondary information of the site:

- Composition of soil/sediment and its use.

- Type of protection (Natural reserve, Park or other).

- Level of preservation (natural and/or anthropic degradation).

- The existence of any stories, myths or legends about the geological site that could make the site more attractive to tourist and may help the MNP to develop a specific protection procedure.

\subsection{Inventory Process}

As parts of the process of geoconservation and protection of potential geosites, details description of sites are required and maximum amount of information are needed [27], therefore the inventory procedure progressively followed the following steps:

- Data acquisition and collection, in which the methodology approach of the study were compiled with most of the data collected during site fieldworks.

- Data compilation using spatial data analysis (GIS) based on geological, geomorphological, geodiversity and biodiversity. This provides more scientific and touristic details about the sites and improves the geological map of Isalo National Park. This step usually starts with the scanning of filled sheets from the field.

- Inventorying geotopes according to their code, and that will be included in a Madagascar database (e.g. geotopes database of national parks).

Final compilation: this database compiled by a software will be hosted in a plat-form. 


\begin{tabular}{|c|c|c|c|c|}
\hline $\begin{array}{l}\text { PROPERTY } \\
\text { Property of the terrain or the } \\
\text { geology object: name and logo } \\
\text { Symbol of Institution, protected } \\
\text { area (National Park), association, } \\
\text { NGO, private, common....) }\end{array}$ & $\begin{array}{l}\text { TOPONYM } \\
\text { Used to identify, both } \\
\text { the basic typology of the site } \\
\text { (geosite/paleosite/geomorphosite) } \\
\text { and name of the site and also the } \\
\text { history that accompanies it. } \\
\text { e.g Geosite_skull of Isalo }\end{array}$ & \multicolumn{2}{|c|}{$\begin{array}{l}\text { LOCATION } \\
\text { Gives some geographic } \\
\text { informations } \\
\text { of the place as precise as } \\
\text { possible }\end{array}$} & $\begin{array}{l}\text { COORDINATES } \\
\text { geographic coordinates are } \\
\text { expressed in degrees, minutes } \\
\text { and seconds }\end{array}$ \\
\hline \multicolumn{3}{|c|}{$\begin{array}{l}\text { DESCRIPTION OF GEOSITEIGEOMORPHOSITE/PALEOSITE } \\
\text { This part must raise a detail description of the site (geosite ; paleosite ; } \\
\text { geomorphosite), taking account both observations in field work and } \\
\text { analysis from reference documents }\end{array}$} & \multirow[t]{3}{*}{$\begin{array}{l}4 \text { parts characteri } \\
\text { TYPOLOGY: sing } \\
\text { elements } \\
\text { STRUCTURE: is } \\
\text { punctual, areal.... } \\
\text { EXPOSITION TY } \\
\text { USABILITY OF A } \\
\text { - Position:giv } \\
\text { the site in relation } \\
\text { ipogeous, submer } \\
\text {-Modality of a } \\
\text { boat..... } \\
\text {-accessibility }\end{array}$} & $\begin{array}{l}\text { nysic data of the site } \\
\text { nent or combination of } \\
\text { ometry of the site (linear, } \\
\text { ural , artificial } \\
\text { OBJECT } \\
\text { detailed of the position of } \\
\text { surface: epigeous; } \\
\text { to the site by foot, bike, }\end{array}$ \\
\hline \multicolumn{3}{|c|}{$\begin{array}{l}\text { DESCRIPTION OF GENETIC IEVOLUTIVE PROCESS } \\
\text { Gives more explanation about the genesis/geomorphogenesis of the site }\end{array}$} & & \\
\hline $\begin{array}{l}\text { COMPILER } \\
\text { Randrianaly Hasina Nirina }\end{array}$ & & & & PAGE 2 \\
\hline
\end{tabular}

Figure 3. Prototype detailed of inventory sheet "number two".

\begin{tabular}{|c|c|c|c|c|}
\hline $\begin{array}{l}\text { PROPERTY } \\
\text { Property of the terrain or the geol- } \\
\text { ogy object: name and logo Symbol of } \\
\text { Institution, protected area (National Park) } \\
\text { association, NGO, private, common....) }\end{array}$ & $\begin{array}{l}\text { TOPONYM } \\
\text { Used to identify, both } \\
\text { the basic typology of the site } \\
\text { (geosite/paleosite/geomorphosite) } \\
\text { and name of the site and also the } \\
\text { history that accompanies it. } \\
\text { e.g Geosite_skull of Isalo }\end{array}$ & $\begin{array}{l}\text { LO } \\
\text { Give } \\
\text { info } \\
\text { cise }\end{array}$ & $\begin{array}{l}\text { TION } \\
\text { ome geographic } \\
\text { tions of the place as pre- } \\
\text { possible }\end{array}$ & $\begin{array}{l}\text { COORDINATES } \\
\text { geographic coordinates are } \\
\text { expressed in degrees, minutes } \\
\text { and seconds }\end{array}$ \\
\hline \multirow{2}{*}{\multicolumn{3}{|c|}{$\begin{array}{l}\text { SOIL characteristics of the given area: Farmed, Vegetate, } \\
\text { Wooded, Urbanized............... } \\
\text { FLOOR: identify the composition of floor: silt, gravel, } \\
\text { outcrop rock............... }\end{array}$}} & \multicolumn{2}{|c|}{$\begin{array}{l}\text { NATURAL AND HUMAN DEGRADATION RISK: } \\
\text { State of the degradation risk of the natural area }\end{array}$} \\
\hline & & & \multicolumn{2}{|c|}{$\begin{array}{l}\text { PROTECTION PROPOSAL I INSTITUTION } \\
\text { of SPECIFIC PROTECTION AREA: } \\
\text { proposal of protection measures }\end{array}$} \\
\hline \multicolumn{3}{|c|}{$\begin{array}{l}\text { PROTECTION AND LIMITS Name and definition of the area: } \\
\text { Typology of the protected area (National park, Natural reserve, } \\
\text { Minerary park..................) }\end{array}$} & \multicolumn{2}{|c|}{$\begin{array}{l}\text { LEGENDS/FOLKS: stories, anecdotes, } \\
\text { myths and legends drawn primarily from } \\
\text { the site/area. }\end{array}$} \\
\hline COMPILER & & & \multicolumn{2}{|r|}{ PAGE 3} \\
\hline
\end{tabular}

Figure 4. Prototype detailed of inventory sheet "number three”. 


\section{Results and Discussion: Why Geosites/Geomorphosites/Paleosites Should Be Classified of on the Basis of Tourist Value?}

Madagascar's economy relies heavily on tourism. In fact all National parks in Madagascar are designed to attract tourism both international and local tourists. That is the reason why geoheritage inventory takes an important place by valuing tourism

Geoheritage inventory system existed [15], [17] and [22], however they cannot be directly adopted to the Madagascar`s geosites, either the inventory sheets were designed to cover a regional scale or they are lacking in detail. Besides, geosites found in Isalo National Parks and in other parks in Madagascar are so specific and unusual, which require more detail inventory sheets that can be flexible and easy to change.

\subsection{Identification and Inventory of Sites: Simulation Process in Isalo Park}

According to all information gathered in each inventory sheet, the identification and inventory, add more details explanation and understanding of the potential geosite/paleosite/geomorphosite. Figures 5-7 are examples of completed sheets. The application of this inventory procedure is advantageous for Isalo park because the park is a protected area which hides numerous geological objects that can be seen on several angles as a touristic attractive object, recreational and educational. The main goal is that these should become more easier understood by the general public.

\subsection{Potential Benefits of Using Geosite Cards}

The proposed inventory sheets here may be used both as a check list (Figure 1) and as a database (Figures 5-7).

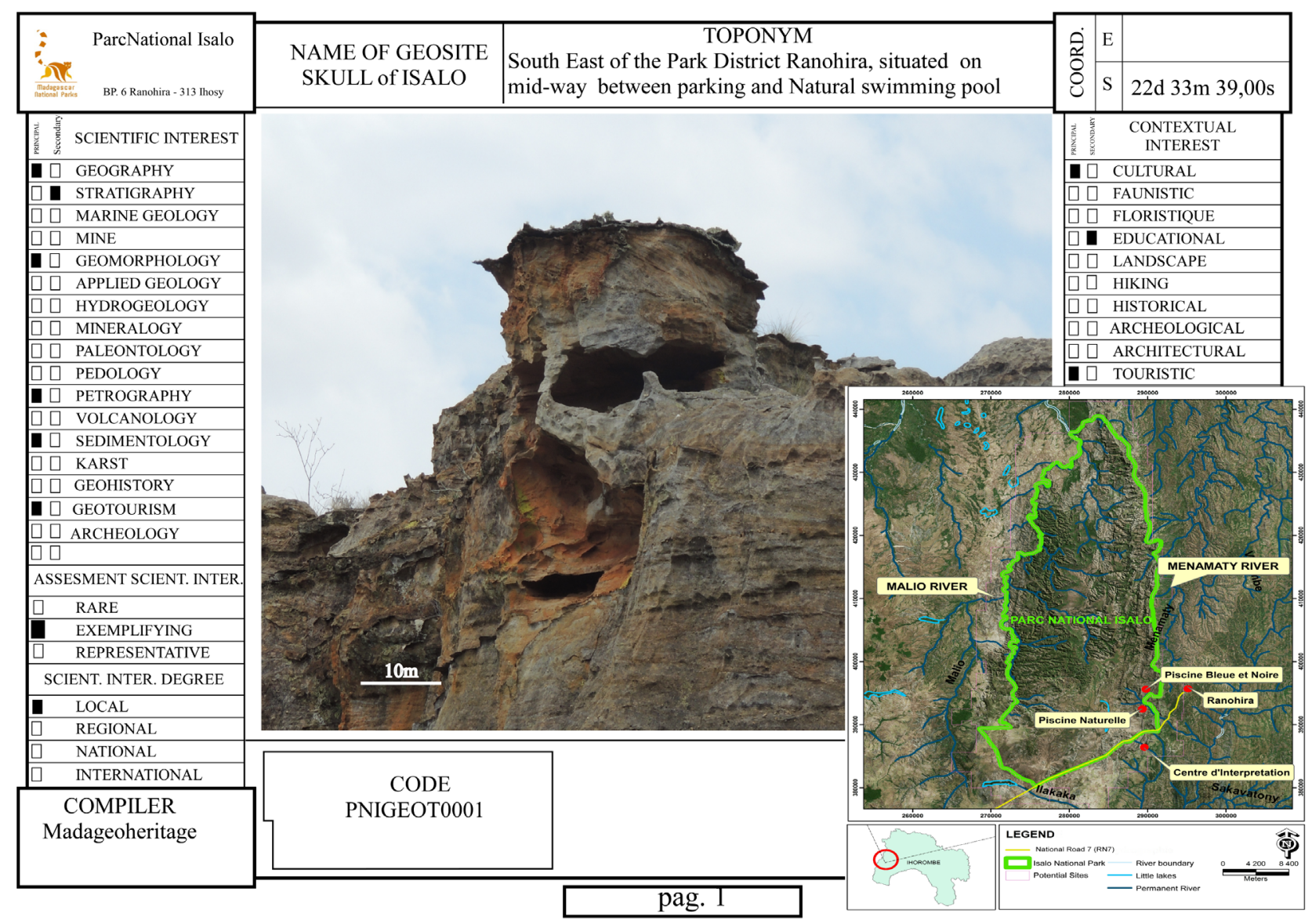

Figure 5. Digitalizing format of an inventory sheet “number one” of the geosites called “Crâne de L'Isalo”. 


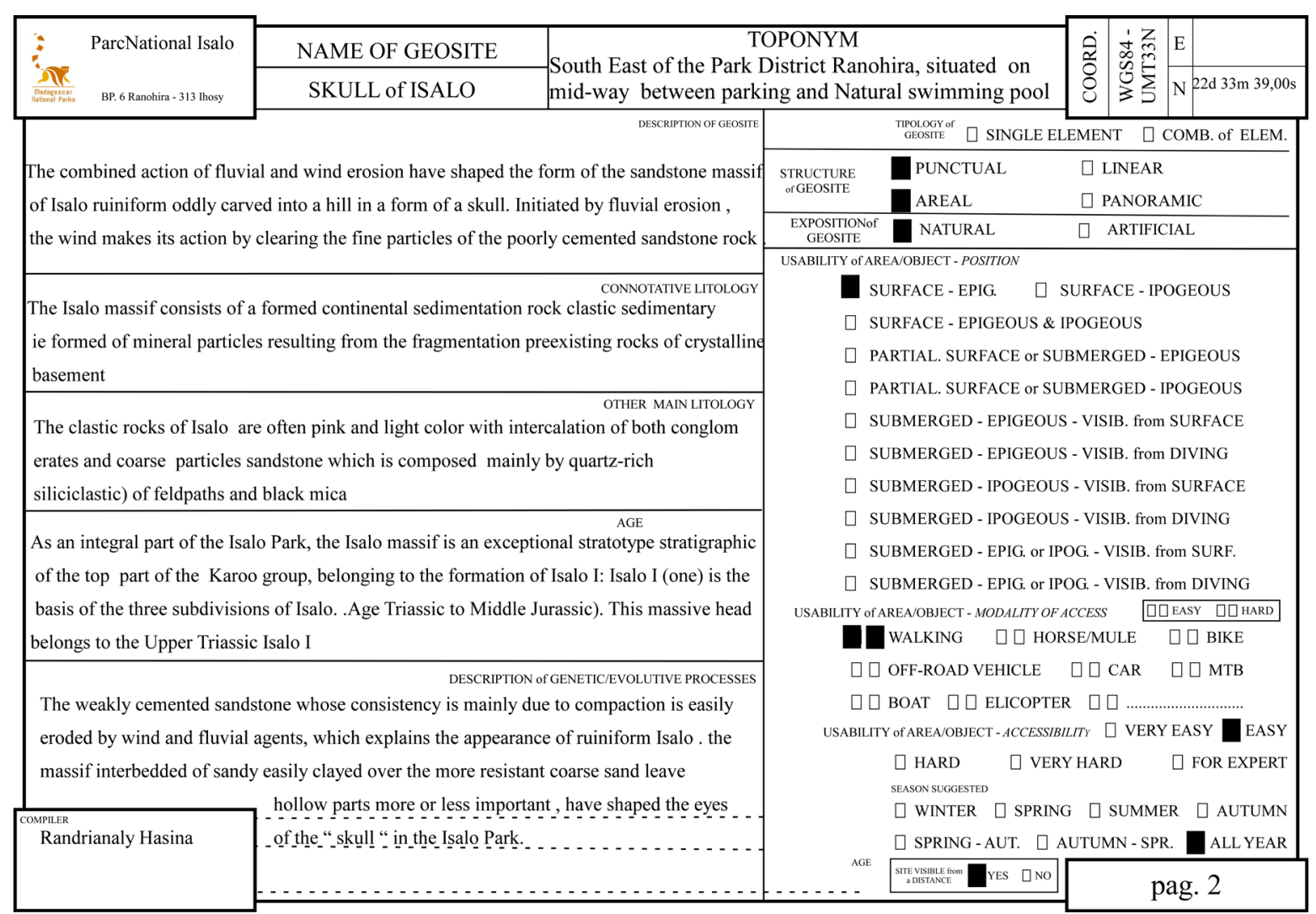

Figure 6. Digitalizing format of an inventory sheet “number two" of the geosites called "Crâne de L'Isalo".

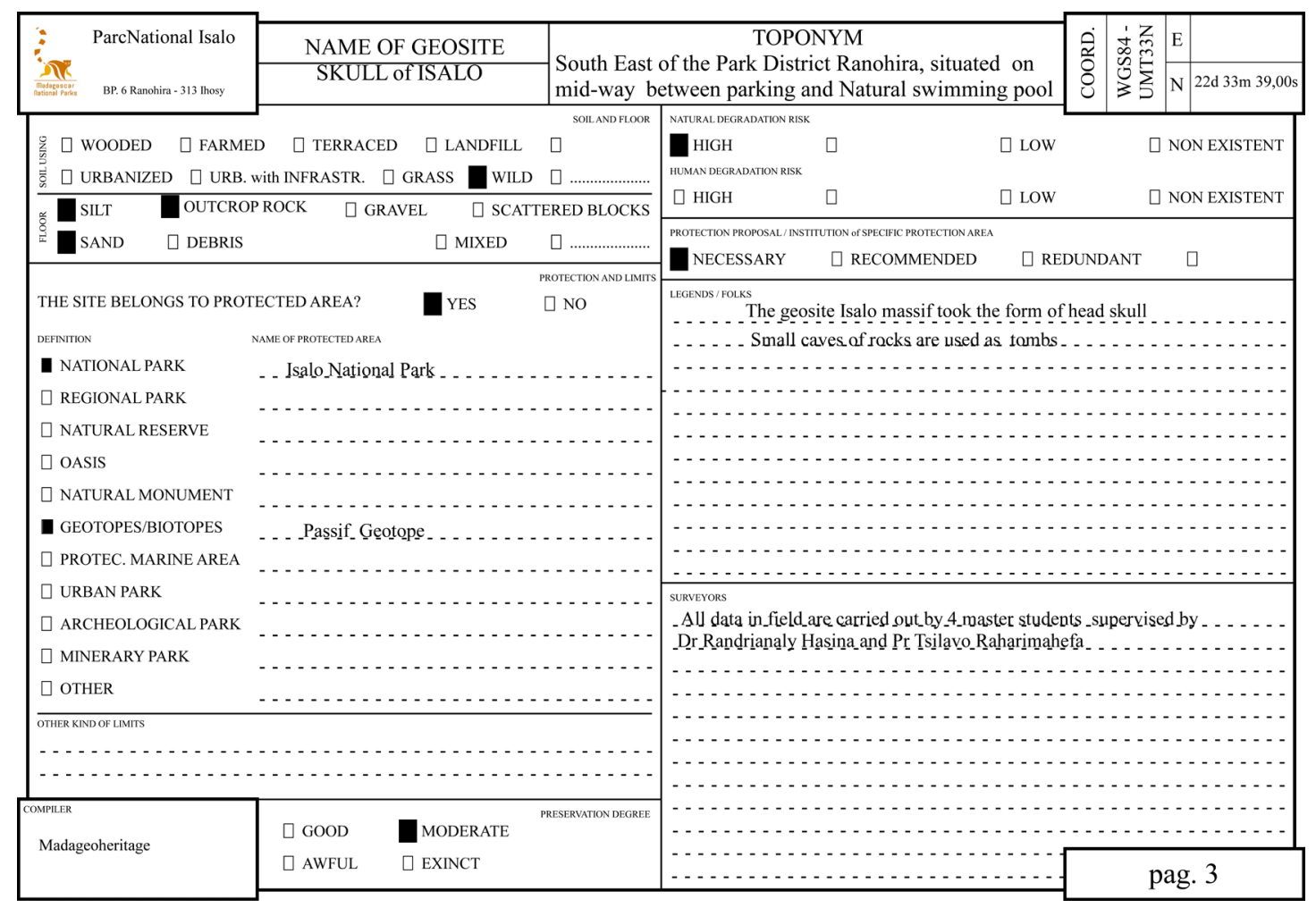

Figure 7. Digitalizing format of an inventory sheet “number three” of the geosites called "Crâne de L'Isalo”. 
As check list, the inventory sheets could be used directly on the field in order to describe and formalize a site as a geo- and/or paleo-site. The sheets allow us to classify every geographic, geological, geomorphological information on a site. Also, these allow us to collect information such as accessibility and point of interest.

In contrast to the ISPRA format, our inventory sheets included a section to record any previous histories, myths and legends about the geosites. Randrianaly et al. 2015 ([5]), explains the importance of stories about geological and paleontological features. Knowing the histories, the myths or legends about the geosites helped the compiler during his or her approach with the native and the locals. To attract visitor (scientists or tourists) these historical values can be included in the geosite database and could be published in museums, libraries and even on the park websites.

As an example, one geosite located in the East of the park is illustrated in the Figure 6.

\subsection{The Importance of Inventorying}

According these inventory sheets, we strongly affirm that inventory and evaluation of the geoheritage are the best way to tackle and to overcome the challenge associated with the implementation of the geoconservation in Madagascar. The completion of the inventory of geosites within the Isalo Park shows that geosites values are based in four criteria (Figure 8) [5].

-The inventory of each geosite promotes its scientific values (rarity, integrity and diversity) [16].

-The inventory data brings additional explanation of the geology for scientists and promote local and international tourism, and attract visitor [32].

-Geosites could be used as additional esthetic, ecological and cultural values ([33] and [34]). For example, the deep canyon with evergreen forest in Isalo National Park is considered as a natural beauty because of the landscape and also known as a sacred/holy site.

-The potentialities of the sites highlighted the geotourism, a sustainable strategy towards the ecotourism for Madagascar, which may help to reduce poverty and may improve and create a more sustainable development.

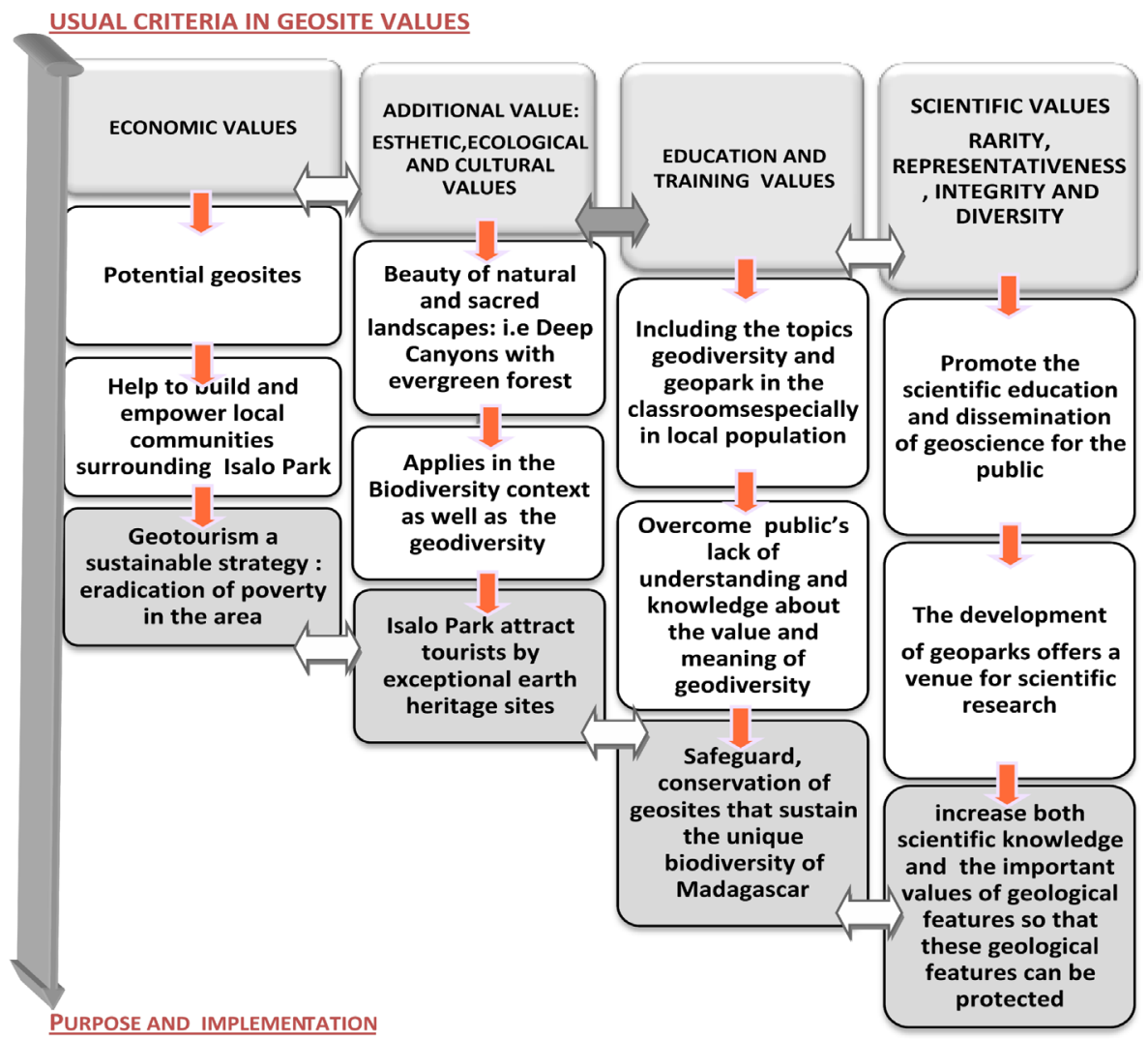

Figure 8. Synthesis graph of geosites values relevant to the current issues to Madagascar (Randrianaly et al. 2015). 
These results showed that inventorying geosites are not only restricted to scientific researches but also help to promote the educational, socio cultural, ecological values of the park.

\section{Conclusions}

To maintain a sustainable natural ecosystem, we should consider and protect the geosites. Their identification allows a better understanding of geological heritage, which should be kept for future generations.

However, in order for a geological site to be a part of the geological heritage, it must be acknowledged and must be the subject of collective ownership.

We proposed for the first time the prototypes of inventory sheets of any geosites. The creation of these sheets was based on the inventory done within the Isalo National Park and was based on the knowledge of the sites and their issues. The inventory of Isalo's geosites was completed in order to produce a plan of action and to improve the management work plan for the park.

The uses of these inventory sheets have resulted into the creation of digital database that integrated geological sites of special interest in the area. In addition, these prototypes can be published online in other media in order to promote the disclosure of all necessary information to implement improve the geotourism sector.

The inventory works demonstrate that it is possible to apply the same thematic areas in remote places which are so distant and different.

\section{Acknowledgements}

We wish to sincerely thank the cooperation with Italian Superior Institute Superior for Environmental Protection and Research (ISPRA: “Istituto Superiore per la Protezione e la Ricerca Ambientale") giving us the authorization for using and modifying their inventory sheet. We are also very grateful to Madagascar National Parks for collaboration and interest with Madageoheritage for the instauration of the geotourism as the project pilot in National Isalo Park. Special thanks are given to journal's GEP editor and to the two reviewers: their comments and input are appreciated.

\section{References}

[1] Ehsan, S., Leman, M.S. and Ara Begum, R. (2013) Geotourism: A Tool for Sustainable Development of Geoheritage Resources. Advanced Materials Research, 622-623, 1711-1715. http://dx.doi.org/10.4028/www.scientific.net/AMR.622-623.1711

[2] Bujdosó, Z., Dávid, L., Wéber, Z. and Tenk, A. (2015) Utilization of Geoheritage in Tourism Development. ProcediaSocial and Behavioral Sciences, 188, 316-324. http://dx.doi.org/10.1016/j.sbspro.2015.03.400

[3] Gray, M. (2005) Geodiversity and Geoconservation: What, Why and How? The George Wright Forum, 22, 4-12.

[4] Robinson A.M. and Percival, I.G. (2011) Geotourism, Geodiversity and Geoheritage in Australia-Current Challenges and future Opportunities. Proceedings of the Linnean Society of New South Wales, 132, 1.

[5] Randrianaly, H.N., Raharimahefa, T., Rajaonarivo, A., Di Cencio, A. and Tolimasy, D.H. (2015) Instauration of Geopark Pilot: Preliminary Approach in Implementation Process of Geoconservation at Isalo National Park, Madagascar. Journal of Geoscience and Environment Protection, 3, 25-40. http://dx.doi.org/10.4236/gep.2015.37004

[6] Gordon, J.E., Barron, H.F., Hansom, J.D. and Thomas, M.F. (2012) Engaging with Geodiversity-Why It Matters. Proceedings of the Geologists' Association 123, 1-6. http://dx.doi.org/10.1016/j.pgeola.2011.08.002

[7] De Lima, F.F., Brilha, J.B. and Salamuni, E. (2010) Inventorying Geological Heritage in Large Territories: A Methodological Proposal Applied to Brazil. Geoheritagen, 2, 91-99. http://dx.doi.org/10.1007/s12371-010-0014-9

[8] Costa, F.L. (2011) Volcanic Geomorphosites Assessment of the Last Eruption, on April to May 1995, within the Natural Park of Fogo Island, Cape Verde. Geojournal of Tourism and Geosites, 8, 167-177.

[9] Crofts, R. and Gordon, J.E. (2015) Geoconservation in Protected Areas. Protected Area Governance and Management, 18, 531-568.

[10] Vallan, D. (2000) Influence of Forest Fragmentation on Amphibian Diversity in the Nature Reserve of Ambohitantely, Highland Madagascar. Biological Conservation, 96, 31-43. http://dx.doi.org/10.1016/S0006-3207(00)00041-0

[11] Hilton-Taylor, C. (2000) 2000 IUCN Red List of Threatened Species (IUCN).

[12] Vieilledent, G., Cornu, C., Sanchez, A.C., Pock-Tsy, J.-M.L. and Danthu, P. (2013) Vulnerability of Baobab Species to Climate Change and Effectiveness of the Protected Area Network in Madagascar: Towards New Conservation Priori- 
ties. Biological Conservation, 166, 11-22. http://dx.doi.org/10.1016/j.biocon.2013.06.007

[13] Raharimahefa, T. (2013) Geoconservation and Geodiversity for Sustainable Development in Madagascar. Madagascar Conservation \& Development, 7, 126-134. http://dx.doi.org/10.4314/mcd.v7i3.5

[14] Errami, E., Schneider, G., Ennih, N., Randrianaly, H.N., Bendaoud, A., Noubhani, A., Norman, N., Allan, M., Vasconcelos, L., Costa, L., Al-Wosabi, M., Al-Subbary, A., Mabvuto-Ngwira, P., Okunlola, G., Halliru, S.L., Andrianaivo, L., Siby, S., Ketchem, B., Gauly, M., Hassine, M., Azki, F., Juliette, T., Lattrache, K., Omulo, M. and Bobrowsky, P. (2015) Geoheritage and Geoparks in Africa and the Middle-East: Challenges and Perspectives. In: Errami, E., Brocx, M. and Semeniuk, V., Eds., From Geoheritage to Geopark: Case Studies from Africa and Beyond, Springer, Dordrecht, 3-23. http://dx.doi.org/10.1007/978-3-319-10708-0 1

[15] Wimbledon, W.A.P., Ishchenko, A.A., Gerasimenko, N.P., Karis, L.O., Suominen, V., Johansson, C.E. and Freden, C. (2000) Geosites-An IUGS Initiative: Science Supported by Conservation. In: Barettino, D., Wimbledon, W.A.P. and Gallego, E., Eds., Geological Heritage: Its Conservation and Management, Madrid, 69-94.

[16] Reynard, E., Fontana, G., Kozlik, L. and Scapozza, C. (2007) A Method for Assessing "Scientific" and "Additional Values” of Geomorphosites. Geographica Helvetica, 62, 148-158. http://dx.doi.org/10.5194/gh-62-148-2007

[17] Fuertes-Gutiérrez, I. and Fernández-Martínez, E. (2012) Mapping Geosites for Geoheritage Management: A Methodological Proposal for the Regional Park of Picos de Europa (León, Spain). Environmental Management, 50, 789-806. http://dx.doi.org/10.1007/s00267-012-9915-5

[18] Ghiraldi, L., Coratza, P., de Biaggi, E., Giardino, M., Marchetti, M. and Perotti, L. (2009) Development and Usage of Geosites: New Results from Research and Conservation Activities in the Piemonte Region (Italy). Studia Universitatis Babes Bolayai, Geologia, 54, 23-26. http://dx.doi.org/10.5038/1937-8602.54.2.5

[19] Seijmonsbergen, A.C., De Jong, M.G.G. and De Graaff, L.W.S. (2009) A Method for the Identification and Assessment of Significance of Geomorphosites in Vorarlberg (Austria), Supported by Geographical Information Systems. Memorie Descrittive Della Carta Geologica d'Italia, 87, 163-172.

[20] Comănescu, L. and Dobre, R. (2009) Inventorying, Evaluating and Tourism Valuating the Geomorphosites from the Central Sector of the Ceahlău National Park. GeoJournal of Tourism and Geosites, Year II, 3, 86-96.

[21] Henriques, M.H., dos Reis, R.P., Brilha, J. and Mota, T. (2011) Geoconservation as an Emerging Geoscience. Geoheritage, 3, 117-128. http://dx.doi.org/10.1007/s12371-011-0039-8

[22] Brilha, J. (2015) Inventory and Quantitative Assessment of Geosites and Geodiversity Sites: A Review. Geoheritage, 8, 119-134.

[23] Iosif, D. (2014) Les Géosites des Gorges du Danube en Roumanie: Inventaire, Évaluation, Valorisation. Paris, 10.

[24] Giusti, C. and Calvet, M. (2010) L’inventaire des géomorphosites en France et le problème de la complexité scalaire. Géomorphologie: Relief, Processus. Environnement, 16, 223-244. http://dx.doi.org/10.4000/geomorphologie.7947

[25] Golonka, J., Doktor, M., Miśkiewicz, K., Krobicki, M. and Slolomka, T. (2014) Selected Geosites within a Proposed New Trans-Border Pieniny Geopark (Polish-Slovakian). Acta Geoturistica, 5, 46-63.

[26] Ielenicz, M. (2009) Geotope, Geosite, Geomorphosite. The Annals of Valahia University of Târgovişte, Geographical Series, 9, 7-22.

[27] Lugeri, F., Farabollini, P., Greco, R. and Amadio, V. (2015) The Geological Characterization of Landscape in Major TV Series: A Suggested Approach to Involve the Public in the Geological Heritage Promotion. Sustainability, 7, 41004119. http://dx.doi.org/10.3390/su7044100

[28] Panizza, M. (2001) Geomorphosites: Concepts, Methods and Examples of Geomorphological Survey. Chinese Science Bulletin, 46, 4-5. http://dx.doi.org/10.1007/BF03187227

[29] Bâca, I. (2011) Contributions to Inventory and Assessement of the Geomorphosites in Călimani National Park. Case Study: 12 Apostles Geologic Reserve. Annals of the University of Oradea, Geography Series, 21, 172-180.

[30] Pellitero, R., González-Amuchastegui, M.J., Ruiz-Flaño, P. and Serrano, E. (2011) Geodiversity and Geomorphosite Assessment Applied to a Natural Protected Area: The Ebro and Rudron Gorges Natural Park (Spain). Geoheritage, 3, 163-174. http://dx.doi.org/10.1007/s12371-010-0022-9

[31] Madagascar National Parks Madagascar National Parks. WWW Document. http://www.parcs-madagascar.com/

[32] Jaafar, M., Nordin, A.O.S., Abdullah, S. and Marzuki, A. (2014) Geopark Ecotourism Product Development: A Study on Tourist Differences. Asian Social Science, 10, 42-55. http://dx.doi.org/10.5539/ass.v10n11p42

[33] Hose, T.A. (2006) Geotourism and Interpretation. Geotourism, 221-241.

[34] Joyce, E.B. (2010) Australia's Geoheritage: History of Study, a New Inventory of Geosites and Applications to Geotourism and Geoparks. Geoheritage, 2, 39-56. http://dx.doi.org/10.1007/s12371-010-0011-z 